\title{
DENDROCHRONOLOGICAL DATING OF THE WORLD TRADE CENTER SHIP, LOWER MANHATTAN, NEW YORK CITY
}

\author{
DARIO MARTIN-BENITO ${ }^{*}$ *, NEIL PEDERSON ${ }^{1}$, MOLLY MCDONALD ${ }^{2}$, PAUL KRUSIC ${ }^{3}$, \\ JAVIER MARTIN FERNANDEZ ${ }^{1}$, BRENDAN BUCKLEY ${ }^{1}$, KEVIN J. ANCHUKAITIS ${ }^{1,4}$, ROSANNE D'ARRIGO', \\ LAIA ANDREU-HAYLES ${ }^{1}$, and EDWARD COOK ${ }^{1}$ \\ ${ }^{1}$ Tree-Ring Laboratory, Lamont-Doherty Earth Observatory of Columbia University, 61 Route 9W, Palisades, NY 10964, \\ USA \\ ${ }^{2}$ AKRF, Inc. 440 Park Avenue South, New York, NY 10016, USA \\ ${ }^{3}$ Bolin Centre for Climate Research, Department of Physical Geography and Quaternary Geology, Stockholm University, \\ SE-106 91 Stockholm. Sweden \\ ${ }^{4}$ Woods Hole Oceanographic Institution, Woods Hole, MA 02543, USA
}

\begin{abstract}
On July 2010, archaeologists monitoring excavation at the World Trade Center site (WTC) in Lower Manhattan found the remains of a portion of a ship's hull. Because the date of construction and origin of the timbers were unknown, samples from different parts of the ship were taken for dendrochronological dating and provenancing. After developing a 280-year long floating chronology from 19 samples of the white oak group (Quercus section Leucobalanus), we used 21 oak chronologies from the eastern United States to evaluate absolute dating and provenance. Our results showed the highest agreement between the WTC ship chronology and two chronologies from Philadelphia $(\mathrm{r}=$ 0.36; $\mathrm{t}=6.4 ; \mathrm{p}<0.001 ; \mathrm{n}=280)$ and eastern Pennsylvania $(\mathrm{r}=0.35 ; \mathrm{t}=6.3 ; \mathrm{p}<0.001 ; \mathrm{n}=280)$. The last ring dates of the seven best-preserved samples suggest trees for the ship were felled in $1773 \mathrm{CE}$ or soon after. Our analyses suggest that all the oak timbers used to build the ship most likely originated from the same location within the Philadelphia region, which supports the hypothesis independently drawn from idiosyncratic aspects of the vessel's construction, that the ship was the product of a small shipyard. Few late- $18^{\text {th }}$ Century ships have been found and there is little historical documentation of how vessels of this period were constructed. Therefore, the ship's construction date of 1773 is important in confirming that the hull encountered at the World Trade Center represents a rare and valuable piece of American shipbuilding history.
\end{abstract}

Keywords: dendroarcheology, dendroprovenance, eastern United States, oak, Quercus.

\section{INTRODUCTION}

Since at least the time of early Dutch settlement, shipping was one of the most important economic activities of New York City. In 1647 the Dutch West India Company built the first docks and wharfs in New York (Buttenwieser 1987). In 1664, the English occupied and took possession of New Amsterdam, renaming it New York. In 1686, lands and water bodies within the island were

\footnotetext{
*Corresponding author: dario.martin@usys.ethz.ch, dmartinbenito@gmail.com.

Current address: Institute of Terrestrial Ecosystems ETH Zürich, Universitätstrasse 16, 8092 Zürich, Switzerland
}

transferred from the British Crown to the City of New York. Soon after, waterfront property was sold to private owners who in many cases extended their property with landfill. Since that time the coastline around the island of Manhattan has undergone extensive physical alterations (Squires 1992). Cheap and abundant fill materials such as rocks, earth, and refuse, were placed behind wooden barriers or within wood structures to create new land. Earlier wharfs and abandoned merchant ships were often a component of the fill in newly constructed land.

On July 13, 2010, archaeologists monitoring excavation for the Vehicular Security Center at the 


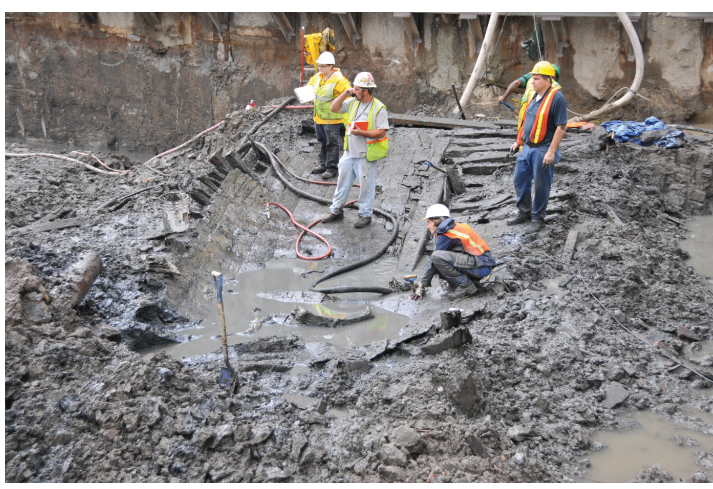

Figure 1. The ship as it was found during excavation for a Vehicular Security Center at the World Trade Center Site in Lower Manhattan. The ship was $6.7 \mathrm{~m}$ below current ground surface. Courtesy of the Lower Manhattan Development Corporation.

World Trade Center site (hereafter WTC) encountered the intact remains of a portion of a ship's hull (Figure 1). The vessel remnant was recovered from landfill deposits approximately one city block west of Manhattan's original shoreline at Greenwich Street and approximately $300 \mathrm{~m}$ east of the present coastline (AKRF 2013). The World Trade Center was built between 1966 and 1971 by the Port Authority of New York and New Jersey on land that had been filled between roughly 1760 and 1818 CE. The location where the ship was found had been infilled by the 1790s (AKRF 2013). Our hypothesis is that the ship was built in the mid to late 18th Century and was sunk, either deliberately or accidentally, less than thirty years later.

\section{THE IMPORTANCE OF DENDROPROVENANCING FOR MOBILE WOODEN ARTIFACTS}

Determining the dates of construction of wooden structures was one of the first applications of dendrochronological techniques (Douglass 1921, 1929). A major limitation of dating shipwreck material is establishing the origin of the timbers used for construction and the shipyard where it was built (Farrell and Baillie 1976). A similar limitation is encountered when dating other mobile wooden artifacts such as furniture or artwork (Haneca $e t$ al. 2005; Bridge 2012). Thus, determining the timber's origin or provenance is performed simultaneously with the process of correctly dating the ship's timbers. This process, called dendroprovenancing the use of dendrochronological methods to identify the region of origin for wooden material - has been successfully used in Europe (Bridge 2012). Success in dendroprovenancing requires a dense network of site regional chronologies for different species from potential areas of origin. Such a network exists for the eastern United States where tree-ring width chronologies have been developed for many sites representing many different tree species (e.g. Stahle and Hehr 1984; Stahle et al. 1985, 1998; Stahle and Cleaveland 1988; Cook et al. 1999; Pederson et al. 2012a, 2012b). In addition, previous dendroarchaeological work to date historical buildings in the eastern United States (Grissino-Mayer et al. 2012; Therrell and Stahle 2012), including the Independence Hall in Philadelphia, Pennsylvania (Cook and Callahan 1992), has allowed for the extension of tree-ring records both in space and back in time. This kind of network expansion in turn facilitates further dendroarcheological research (Stahle and Wolfman 1985).

Dendroarchaeology has been a less common practice in the eastern part of the United States than in the Southwest where it originated (Robinson 1976; Stahle and Wolfman 1985; Grissino-Mayer 2009). Although numerous structures have been successfully dated in the eastern United States (e.g. Cook and Callahan 2004, 2005; Krusic et al. 2004; Grissino-Mayer et al. 2012; Therrell and Stahle 2012), few have been published in academic journals or had their findings and data made publicly available (but see e.g. Huber (2006), McDonald (2006), and the Boston Dendrochronology Project (http://www.dendrochronology.net/boston_project. asp\#)). Similar to the southeastern United States (Grissino-Mayer 2009), the Northeast has often been considered too mesic to develop tree-ring width chronologies that show sufficient agreement with other chronologies at the regional level to be used to accurately and precisely date wood artifacts and structures. However, because there is indeed a pervasive and well-established drought-sensitivity in trees across various ecosystems in the eastern United States (Cook and Jacoby 1977, 1983; Stahle and Hehr 1984; Stahle et al. 1985; Cook et al. 1999; Pederson et al. 2012a, 2012b), including across forest strata and gradients of land-use history (Pederson 
et al. 2012b), the eastern United States tree-ring network can be used to date and provenance historic timbers.

Dendrochronological dating and provenancing of recovered shipwreck remains has been performed in Europe to vessels from the Baltic countries (e.g. Bonde and Christensen 1993; Daly 2007; Daly and Nymoen 2008) and in one documented instance in North America (Pickard et al. 2011). Dendroprovenancing of maritime timbers has also been successfully demonstrated, albeit in the case where the date of construction itself was not in question (Carrell 2003). Here we report on what is, to the best of our knowledge, the first successful application of dendrochronology for dating the remains of a ship on the northeastern coast of the United States. The effort of dating and determining the origin of timbers from a wreck in New York City, one of the world's busiest ports since the 1600s, presents several challenges, not the least of which is the diverse set of possible origins and construction materials for ships trading in the region over the last several centuries.

\section{MATERIAL AND METHODS}

\section{The Ship}

The WTC Ship was found approximately $6.7 \mathrm{~m}$ below current ground surface, oriented eastto-west. The stern section of the hull, which pointed west, was the most intact section measuring $10 \mathrm{~m}$ long and $4.5 \mathrm{~m}$ wide (Figure 2). The ship had been bisected by a slurry wall built as part of the ongoing construction along the former line of Washington Street. A small section of the bow was later found on the east side of the slurry wall. The ship remnant consisted of the lower hull of a vessel. With the exception of a small orlop deck at the stern end, none of the decks or upper portions of the ship survived. The physical characteristics of the ship remnant, including the broad beam, shallow draft, and forward-stepped mast, appeared consistent with a class of ship known as the Hudson River sloop, designed to transport goods and passengers along the Hudson River (AKRF 2013).

Wood identification analysis showed that a variety of wood types had been used to serve

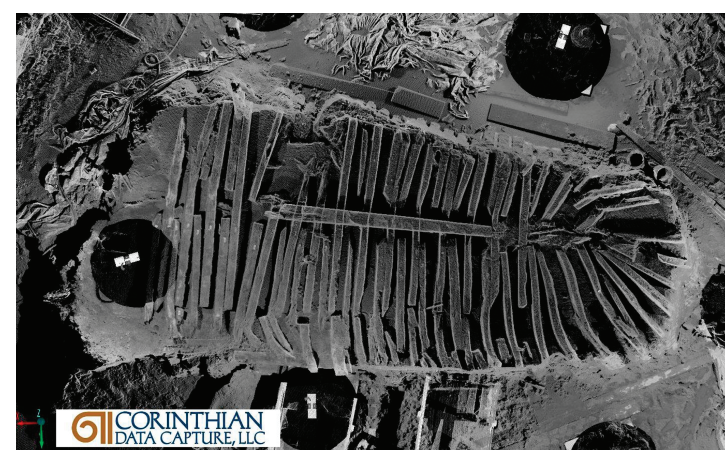

Figure 2. Vertical 3D laser scanning image of the ship in situ World Trade Center Site in Lower Manhattan. The hull of the ship was $10 \mathrm{~m}$ long and $4.5 \mathrm{~m}$ wide. Courtesy of the Lower Manhattan Development Corporation and Corinthian Data Capture.

particular functions in the ship's construction (Robert A. Blanchette, personal communication September 9, 2010). The keel (the spine of the ship) was made of hickory (Carya sp., Figure 4) and the keelson (the member that runs directly above the keel) was white oak (Quercus section Leucobalanus). The sternpost and stern knee, large timbers comprising the rear of the hull, were also white oak (Figure 4). Likewise, the frames of the ship (the essential structure of the hull, including floor timbers, futtocks, and cant frames) were also white oak. The vessel remnant had two layers of planking: outer planking, which formed the exterior of the hull, and ceiling planking, which formed the interior of the hull. In several locations, sections of the vessel's plank floor appeared to be patched with replacement planks. Sample planks taken for species identification showed that several woods were used, including spruce (Picea sp.), pine (Pinus sp.), and oak (Quercus sp.). The orlop deck was also floored in spruce (Picea sp.) planks. All of the major timbers of the vessel remnant were hewn and principally fastened by iron spikes.

Evidence of shipworm infestation was found in many of the ship's timbers. Examination of a sample of the infested wood determined that a single shipworm species was represented, Lyrodus pedicellatus (Kevin J. Eckelberger, personal communication; August 6, 2010). Lyrodus pedicellatus is a marine bivalve mollusk of the family Teredinidae typically found in warm waters with high salinity. This finding, combined with the absence of 


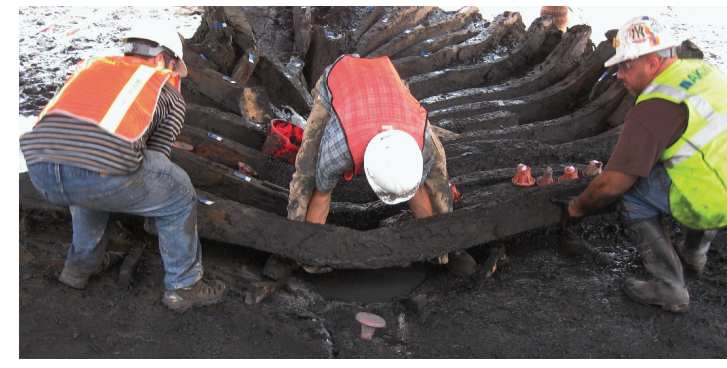

Figure 3. Archeologists carefully labeled and disassembled all individual timbers of the ship. They were packed into storage containers, and transported to the Maryland Archaeological Conservation Laboratory in Saint Leonard, Maryland. Courtesy of the Lower Manhattan Development Corporation.

any shipworm species local to the northeastern United States led to the hypothesis that the larvae may have infested the sternpost when the ship was in the Caribbean (Kevin J. Eckelberger, personal communication; August 6, 2010).

\section{METHODS}

\section{Sampling}

The archaeologists carefully recorded the vessel remnants in situ (Figure 3). Each piece of timber that comprised the structure was labeled with a unique identification number. The hundreds of individual timber elements were then carefully disassembled, packed into a storage container, and transported to the Maryland Archaeological Conservation Laboratory in Saint Leonard, Maryland, where they were submerged in water until sampled. Pieces that were considered to contain a reasonable number of growth rings were selected for sampling. Samples were taken from the mid-section of each piece after wrapping them with duct tape to ensure their stability. A chainsaw was used to cut radial sections from 23 of the logs (see C-SPAN Video Library: World Trade Center Ship. URL: http://www. cspanvideo.org/program/CenterSh). Because all pieces were water logged, they were slowly air dried under cool temperature, to avoid cracking associated with rapid shrinking, before any further preparation. Another potential complication with dating submerged, historical samples is that the wood could have decomposed to such a degree that the structure of the wood would be too degraded for processing. Therefore, strongly decayed pieces were first glued onto wood boards in order to protect them while handling. None of the samples presented any evidence of bark; however, nine samples had sapwood rings (Figure 4), which would suggest that the last dated ring is near the felling date of the tree. Seven samples showed evidence of being squared prior to construction of the vessel, which reduces the amount of rings present and thus the probability of finding the last ring formed before felling (Miles 1997).

\section{Measuring and Crossdating}

After drying, the samples were sanded with progressively finer sandpaper until growth rings were clearly visible (Krusic et al. 1987). Two radii per section were marked along the radial transects containing the maximum number of growth rings and visually crossdated to ensure within-tree relative dating for all the rings in each sample (Stokes and Smiley 1968). Tree-ring widths on all samples were later measured to the nearest $0.001 \mathrm{~mm}$ using a Velmex measuring stage. Internal crossdating of the two radii within each sample was verified using COFECHA (Holmes 1983). Radii from different samples were also relatively dated between themselves. We created the "ship chronology" from the relativelydated series using ARSTAN (Cook, Krusic, Holmes and Peters, version 41d, www.ldeo.columbia.edu/trl) by detrending each series using flexible cubic smoothing spline with a $50 \%$ wavelength cutoff at 32 years to remove age-related trends and the possible effect of stand dynamics and to leave most of the high frequency variability in the time series. These detrended series were averaged using a biweight robust estimation of the mean to create a mean WTC chronology.

Fortunately, all but one of the timbers sampled were identified as oaks from the white oak group (Quercus section Leucobalanus). Having multiple samples of oak for comparison improves the likelihood of dating archaeological timbers of unknown site origin. Perhaps just as important for provenance work, the keel of the vessel was 

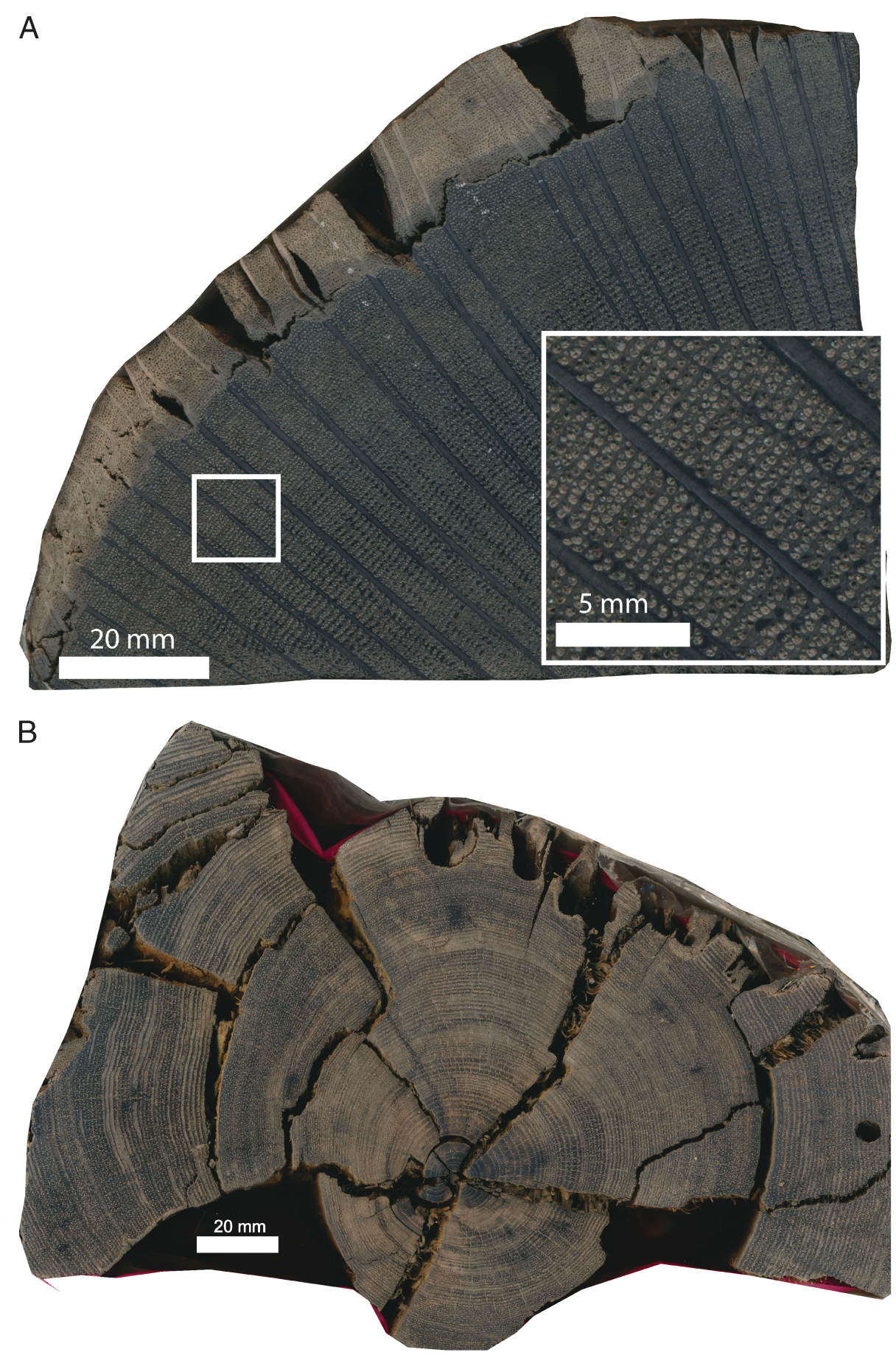

Figure 4. Oak, Quercus sp., sample (A) and hickory, Carya sp., keel sample (B). Box in image (A) shows the general slow growth of these trees, suggesting they most likely originated from old growth forests. 


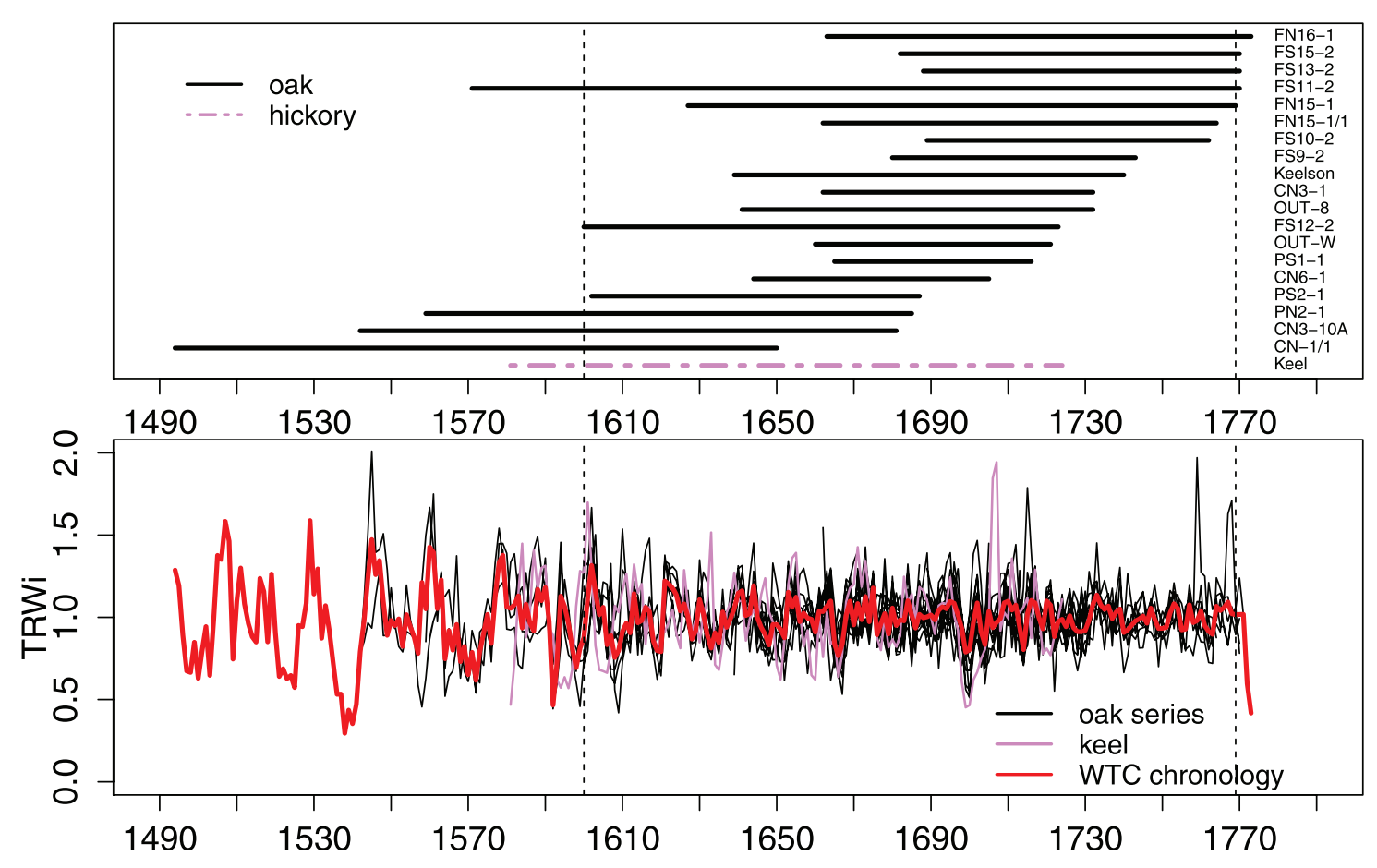

Figure 5. Top, bar graph of time spans for all WTC ship timbers dated. Bottom, plot of the 19 ring-width indices from the WTC ship oak samples (black) and their mean (red; 280 years; time span: 1494-1773). The strong mean interseries Spearman rank correlation $(0.458 ; \mathrm{p}<0.001)$ suggests a common geographical origin for all the timbers. In both graphs, results for the keel (hickory) are shown in dashed purple.

identified as a hickory (Carya sp.), what we believe to be shagbark hickory (Carya ovata (Mill) K. Koch). The presence of hickory greatly reduces the possible provenance to the eastern United States or to East Asia (Manos and Stone 2001), the latter of which is unlikely. Therefore, the WTC resulting residual chronology from ARSTAN containing all successfully crossdated samples was used for absolute dating by comparing it with master tree-ring width chronologies for white oaks from 21 different sites across the northeastern United States (Figure 6) using COFECHA. We limited this analysis to master chronologies dating back at least to the year $1650 \mathrm{CE}$. Chronologies from several sites were used in an attempt to identify the geographical origin of the wood sample and, in all likelihood, the site of construction of the ship (Bridge 2012). In all cases, we tested 50-year successive periods with 25 -year overlaps against the reference master chronologies using the nonparametric Spearman rank correlation coefficient with significance level of $\mathrm{p}=0.05$.

\section{RESULTS}

There were several limitations to the dating of the World Trade Center vessel timbers. First, the keel, keelson, and seven other timbers were squared off prior to construction. Because of this, there was only a small chance that the last ring formed prior to felling was present on these timbers. Second, although nine samples show signs of curvature and sapwood rings (between 6 and 41; Table 1), which are indicative of the outer surface of a tree stem, no samples were found to have intact bark. Bark is commonly removed during construction or lost after long periods of submersion under water. Third, the sapwood rings in some samples were distorted by waterlogging and were either uniformly extremely narrow or wide with little inter-annual growth variability (Figure 4). These ring patterns reduced our ability to date the outermost rings. The rotten condition of sample $\mathrm{CN}-5-1$, in particular, did not allow for sanding or measuring and was therefore removed from further analysis. 
Table 1. Internal dendrochronological dating results for samples taken from the excavated WTC ship. All correlations (R) are Spearman rank correlations of each individual series against the WTC chronology (built with all other series). The keel was dated against the chronology developed from the WTC oak samples. See Figure 5 for a summary plot of the dating results for all dated samples. Bark edge was not recovered or was completely missing on all the timbers.

\begin{tabular}{|c|c|c|c|c|c|c|c|c|c|c|c|}
\hline \multirow[b]{2}{*}{ Sample } & \multirow[b]{2}{*}{ Species } & \multirow[b]{2}{*}{ Observations } & \multicolumn{3}{|c|}{ Series } & \multicolumn{3}{|c|}{ Years Compared } & \multirow[b]{2}{*}{$\mathrm{R}$} & \multirow[b]{2}{*}{$\mathrm{T}$} & \multirow[b]{2}{*}{$\mathrm{p}$ value } \\
\hline & & & FY & LY & $\mathrm{N}$ & FY & LY & $\mathrm{N}$ & & & \\
\hline FN16-1 & Oak & SWR (15) & 1663 & 1773 & 111 & 1663 & 1770 & 108 & 0.44 & 5.02 & $<0.001$ \\
\hline FS13-2 & Oak & SWR (22) & 1688 & 1770 & 200 & 1688 & 1770 & 83 & 0.49 & 5.09 & $<0.001$ \\
\hline FS11-2 & Oak & SWR (41) & 1571 & 1770 & 202 & 1571 & 1770 & 202 & 0.45 & 7.08 & $<0.001$ \\
\hline FS15-2 & Oak & SWR (21) & 1682 & 1770 & 89 & 1682 & 1770 & 89 & 0.36 & 3.55 & $<0.001$ \\
\hline FN15-1 & Oak & SWR (31) & 1627 & 1769 & 143 & 1627 & 1769 & 143 & 0.46 & 6.22 & $<0.001$ \\
\hline FN15-1/1 & Oak & SWR (19) & 1662 & 1764 & 103 & 1662 & 1764 & 103 & 0.32 & 3.37 & $<0.001$ \\
\hline FS10-2 & Oak & SWR (18) & 1689 & 1762 & 74 & 1689 & 1762 & 74 & 0.55 & 5.54 & $<0.001$ \\
\hline FS9-2 & Oak & SWR (6) & 1680 & 1743 & 64 & 1680 & 1743 & 64 & 0.46 & 4.11 & $<0.001$ \\
\hline Keelson & Oak & SQ & 1639 & 1740 & 102 & 1639 & 1740 & 102 & 0.43 & 4.78 & $<0.001$ \\
\hline OUT-8 & Oak & SWR (18) & 1641 & 1732 & 92 & 1641 & 1732 & 92 & 0.58 & 6.78 & $<0.001$ \\
\hline CN3-1 & Oak & & 1662 & 1732 & 71 & 1662 & 1732 & 71 & 0.43 & 4.01 & $<0.001$ \\
\hline FS12-2 & Oak & SQ & 1600 & 1723 & 124 & 1600 & 1723 & 124 & 0.54 & 7.10 & $<0.001$ \\
\hline OUT-W & Oak & & 1660 & 1721 & 62 & 1660 & 1721 & 62 & 0.39 & 3.27 & $<0.001$ \\
\hline PS1-1 & Oak & SQ & 1665 & 1716 & 52 & 1665 & 1716 & 52 & 0.46 & 3.71 & $<0.001$ \\
\hline CN6-1 & Oak & SQ & 1644 & 1705 & 62 & 1644 & 1705 & 62 & 0.38 & 3.22 & 0.001 \\
\hline PS2-1 & Oak & SQ & 1602 & 1687 & 86 & 1602 & 1687 & 86 & 0.64 & 7.63 & $<0.001$ \\
\hline PN2-1 & Oak & SQ & 1559 & 1685 & 127 & 1559 & 1685 & 127 & 0.61 & 8.71 & $<0.001$ \\
\hline CN3-10A & Oak & SQ & 1542 & 1681 & 140 & 1542 & 1681 & 140 & 0.59 & 8.69 & $<0.001$ \\
\hline $\mathrm{CN}-1 / 1$ & Oak & & 1494 & 1650 & 157 & 1542 & 1650 & 109 & 0.20 & 2.12 & 0.018 \\
\hline CN-5-1 & Oak & & n.d. & n.d. & NA & n.d. & n.d. & n.d. & n.d. & n.d. & n.d. \\
\hline OUT? & Oak & & n.d. & n.d. & 83 & n.d. & n.d. & n.d. & n.d. & n.d. & n.d. \\
\hline FN-11-1/1 & Oak & SQ & n.d. & n.d. & 99 & n.d. & n.d. & n.d. & n.d. & n.d. & n.d. \\
\hline Keel & Hickory & SQ & 1581 & 1724 & 144 & 1581 & 1724 & 144 & 0.25 & 3.06 & 0.001 \\
\hline
\end{tabular}

$\mathrm{FY}=$ first year; $\mathrm{LY}=$ last year, $\mathrm{N}=$ number of years compared; $\mathrm{R}=$ Spearman rank correlation coefficient; $\mathrm{T}=$ student's $\mathrm{t}$-test; SWR $=$ sapwood rings present (number of sapwood rings in parenthesis); $\mathrm{SQ}=$ squared timber. n.d. $=$ no date; NA $=$ not applicable because the conditions of sample CN-5-1 did not allow for sanding and ring counting.

Slightly more than $50 \%$ of the samples (12 of 23) had fewer than 100 rings (Table 1), which is ad hoc considered the minimum desirable number of rings for crossdating historical or archaeological timbers in the eastern United States. Nevertheless, tree-ring patterns in 19 sampled timbers had statistically significant internal crossdating with correlations to the WTC master chronology ranging from 0.20 to 0.62 (all significant at $\mathrm{p} \leq 0.05$; Table 1). There were two oak samples (OUT? and FN-11-1/1) that did not yield any conclusive dating against this local chronology despite having 83 and 99 rings, respectively.

Because of the unknown provenance of the timbers, we first attempted to identify the area where they may have originated. In order to do this, we correlated the portion of our WTC chronology consisting of 5 or more series (i.e. 170 years from 1599 to 1769), against 21 chronologies from the eastern United States. The highest correlation coefficient was with a chronology developed with historical timbers from the Philadelphia area $(\mathrm{r}=0.36, \mathrm{t}=6.40 ; \mathrm{p}<0.001 ; \mathrm{n}$ $=280$ ) followed by a chronology from eastern Pennsylvania $(\mathrm{r}=0.35 ; \mathrm{t}=6.30 ; \mathrm{p}<0.001 ; \mathrm{n}=$ 280). (Table 2; Figure 2). In general, correlations were similar and significant with all but one of the chronologies from the Pennsylvania-New JerseySouthern New York (PANJNY) area (Table 2; Figures 6 and 7). In contrast, correlations with chronologies from the northern Hudson Valley yielded non-significant coefficients, as was also the case for other sites to the south and west of the PANJNY area. 
Table 2. Correlations of the WTC ship oak chronology versus long white oak (Quercus alba) chronologies from the eastern United States. See Figure 7 for a map of correlations. Correlation values are Spearman rank correlation coefficients. Chronology sites are in decreasing order of student's t statistic.

\begin{tabular}{|c|c|c|c|c|c|c|c|c|c|}
\hline \multirow[b]{2}{*}{ Master chronology } & \multicolumn{3}{|c|}{ Years Compared } & \multirow[b]{2}{*}{$\mathrm{R}$} & \multirow[b]{2}{*}{$\mathrm{T}$} & \multirow[b]{2}{*}{$\mathrm{p}$ value } & \multirow[b]{2}{*}{ Lat } & \multirow[b]{2}{*}{ Lon } & \multirow[b]{2}{*}{ Source $^{1}$} \\
\hline & FY & LY & $\mathrm{N}$ & & & & & & \\
\hline Philadelphia & 1494 & 1773 & 280 & 0.36 & 6.40 & $<0.001$ & 40.04 & 75.16 & 3 \\
\hline Eastern Pennsylvania & 1494 & 1773 & 280 & 0.35 & 6.30 & $<0.001$ & 40.00 & 75.30 & 2 \\
\hline Hutcheson Forest Historic & 1494 & 1773 & 280 & 0.32 & 5.60 & $<0.001$ & 40.3 & 74.34 & 1 \\
\hline Uttertown & 1494 & 1773 & 280 & 0.29 & 5.10 & $<0.001$ & 41.19 & 74.42 & 1 \\
\hline Hudson Valley & 1563 & 1773 & 211 & 0.29 & 5.00 & $<0.001$ & 41.46 & 74.08 & 2 \\
\hline Mohonk Preserve & 1494 & 1773 & 280 & 0.27 & 4.70 & $<0.001$ & 41.74 & 74.19 & 1 \\
\hline Eastern New Jersey & 1620 & 1773 & 154 & 0.33 & 4.20 & $<0.001$ & 40.30 & 74.34 & 2 \\
\hline Eastern Massachusetts & 1494 & 1773 & 280 & 0.24 & 4.10 & $<0.001$ & 42.30 & 71.3 & 2 \\
\hline Schunemunk Mountain & 1648 & 1773 & 126 & 0.21 & 3.58 & $<0.001$ & 41.39 & 74.11 & 1 \\
\hline Alan Seeger Nat. Area & 1516 & 1773 & 258 & 0.19 & 3.20 & $<0.001$ & 40.72 & 77.75 & ITRDB \\
\hline VA011 & 1554 & 1773 & 220 & 0.18 & 3.07 & 0.001 & 37.23 & 80.30 & ITRDB \\
\hline VA017 & 1572 & 1773 & 202 & 0.20 & 2.90 & $<0.001$ & 37.55 & 79.48 & ITRDB \\
\hline Albany & 1710 & 1773 & 64 & 0.13 & 2.24 & 0.013 & 42.40 & 74.00 & 2 \\
\hline VA014 & 1615 & 1773 & 159 & 0.11 & 1.89 & 0.030 & 38.30 & 78.21 & ITRDB \\
\hline Albany historic & 1507 & 1773 & 267 & 0.11 & 1.77 & 0.039 & 42.40 & 74.00 & 1 \\
\hline $\mathrm{OH} 003$ & 1666 & 1773 & 108 & -0.09 & 1.57 & 0.941 & 39.54 & 84.24 & ITRDB \\
\hline OH006 & 1628 & 1773 & 146 & 0.08 & 1.26 & 0.104 & 39.59 & 81.00 & ITRDB \\
\hline OH001 & 1629 & 1773 & 145 & 0.06 & 0.98 & 0.164 & 40.53 & 81.45 & ITRDB \\
\hline PA006 & 1662 & 1773 & 112 & 0.06 & 0.97 & 0.166 & 41.19 & 79.13 & ITRDB \\
\hline NC007 & 1620 & 1773 & 154 & 0.05 & 0.76 & 0.225 & 35.53 & 81.56 & ITRDB \\
\hline Prospect Mountain & 1659 & 1773 & 115 & 0.04 & 0.67 & 0.250 & 43.50 & 73.62 & 1 \\
\hline
\end{tabular}

$\mathrm{FY}=$ first year; $\mathrm{LY}=$ last year, $\mathrm{N}=$ number of years compared; $\mathrm{R}=$ Spearman rank correlation coefficient; $\mathrm{T}=$ student's t-test; Lat $=$ latitude $\left({ }^{\circ} \mathrm{N}\right)$; Lon $=$ longitude $\left({ }^{\circ} \mathrm{W}\right)$.

${ }^{1}$ Sources: 1 = Pederson et al. (2012a), 2 = E. Cook, 3 = Cook and Callahan (1992); ITRDB = International Tree-Ring Data Bank.

The strongest evidence for the felling date of the trees prior to construction was found in sample FN-16-1 whose last ring was dated to 1773 (Tables 1 and 2). In addition, there were three other samples dating to 1770 and one dating to 1769. The presence of sapwood in these four samples suggested a close proximity to the missing bark and thus to the cutting year. In contrast, the

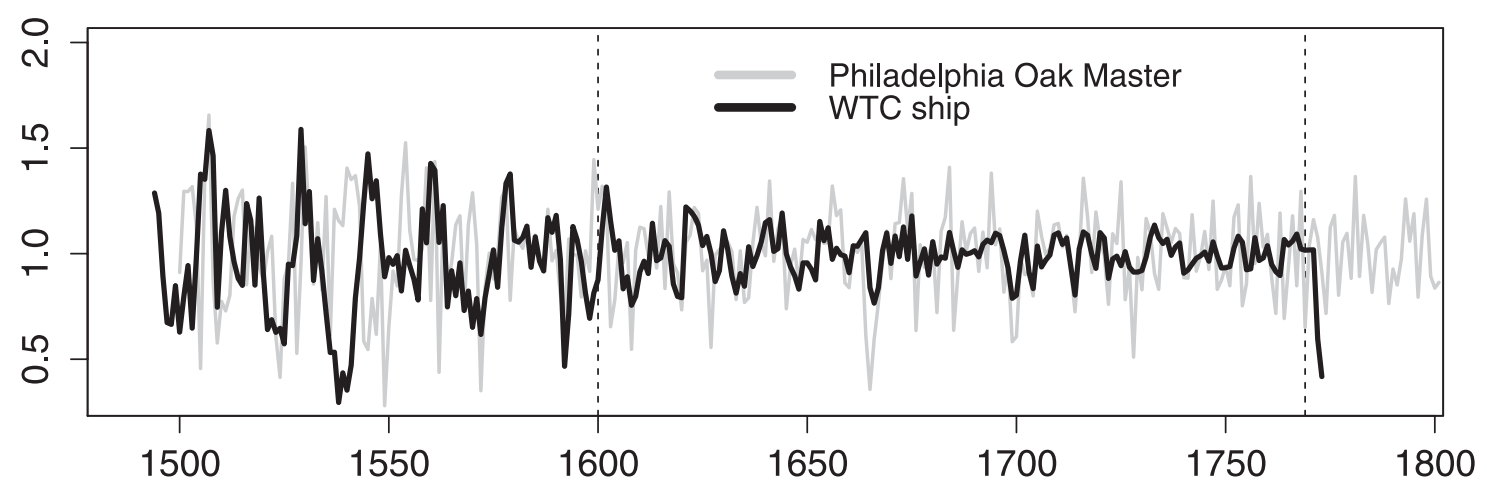

Figure 6. Comparison of the ring-width index of the WTC ship oak chronology (19 samples crossdated) against the Philadelphia area oak master chronology based on living trees and independent archaeological samples. The Spearman rank correlation between the series $(\mathrm{r}=0.36)$ is highly significant $(\mathrm{t}=6.3 ; \mathrm{p}<0.001)$ with an overlap of 280 years. This strong match suggests that the origin of the oak logs used in the WTC ship was from the Philadelphia area. 


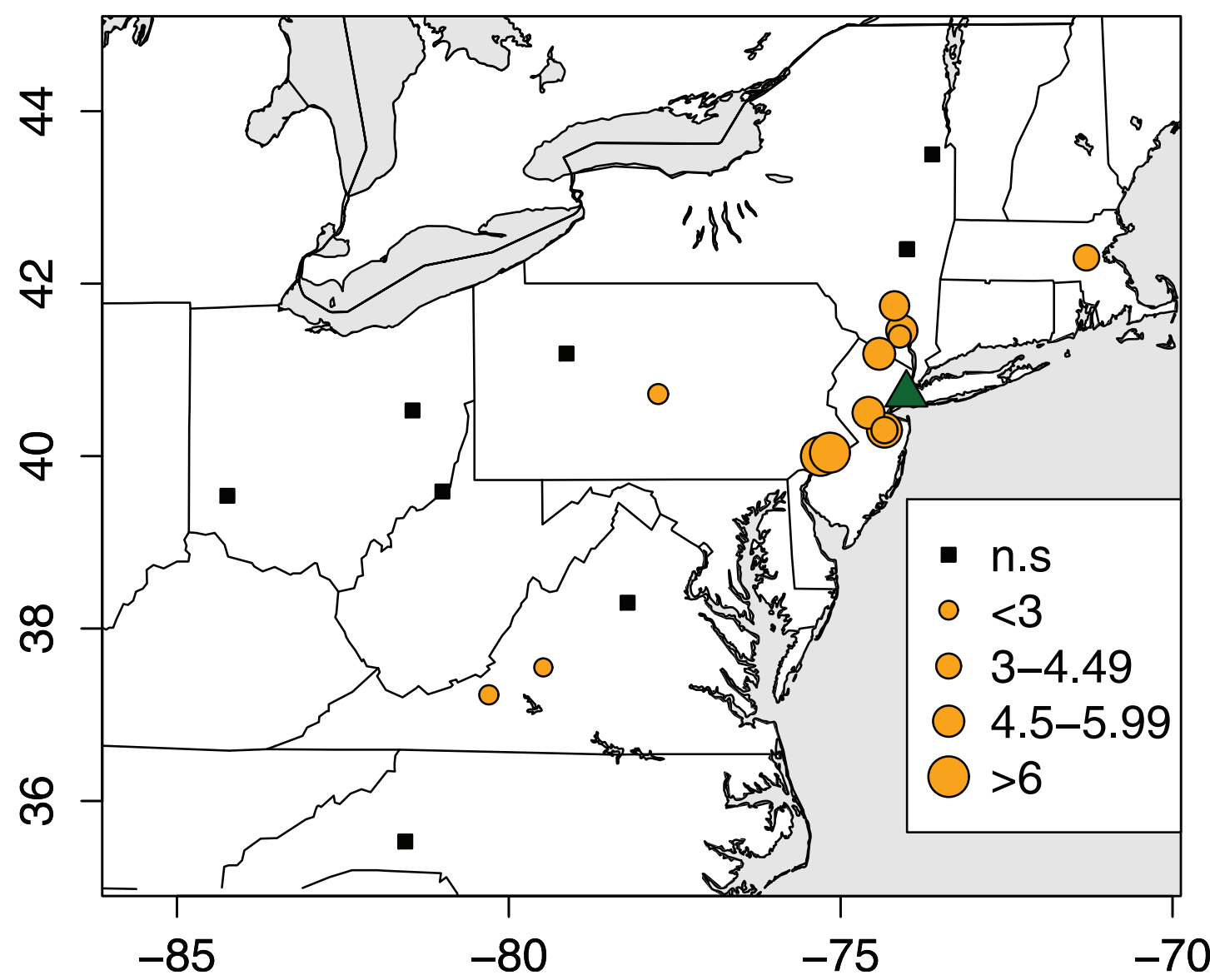

Figure 7. Map of the northeastern United States showing the strength of the WTC ship chronology (green triangle) against site white oak master chronologies. Dot size is proportional to the strength of the t-test value for significant correlations $(\mathrm{p}<0.01)$. Chronology sites with non-significant correlations (n.s.; $p>0.01$ ) are marked by black squares. Higher correlations with master chronologies in eastern Pennsylvania suggest the trees used for building the WTC ship grew in that area.

earliest outer ring date found was 1650 in sample $\mathrm{CN}-1 / 1$. This sample did not have sapwood rings and could be missing an unknown number of heartwood rings. In general, samples from timbers that had been squared for construction and had no sapwood rings yielded earlier dates than those with sapwood rings.

Finally, although the keel was a different species (Carya sp.) than the rest of the samples, we did attempt to crossdate it against the WTC chronology. Although there is some confidence in an outer date of 1724 for the keel, the statistics are weak $(r=0.25)$ and the date should be considered provisional until more hickory chronologies covering the mid-17th Century become available for the eastern United States.

\section{DISCUSSION}

\section{Dendroprovenance}

A ship mainly built with timbers from the white oak group and found in New York City could have many possible origins. Oak species of Quercus section Leucobalanus thrive in different parts of the world and include some of the most widely used timber oak species such as Quercus alba L. (East North America), Q. petraea (Matt.) Liebl and $Q$. robur L. (Europe and West Asia) or Q. aliena Blume (East Asia) (Nixon 2006). From the 17th Century onwards there was constant traffic across the Atlantic Ocean, so the WTC ship could have been built at a shipyard in either Europe or North America. At least one study has documented a 17th 
Century ship wrecked off the North American coast and built with oaks from western France (Carrell 2003). The presence of an essential piece of the ship like the keel made of hickory, however, indicates that the place of construction for this ship is likely to be the eastern United States. It is estimated that by the 1770 s at least $40 \%$ of all British ships were built with American timbers (Williams 1992; p. 93), but the possibility remains that the original keel had been replaced with American timbers. Therefore, we focused dating the WTC timbers against site master chronologies from the eastern United States.

Our results showed the strongest agreement between the WTC chronology and two master white oak ( $Q$. alba) chronologies from Philadelphia and eastern Pennsylvania (Table 2; Figure 7). Lower but significant correlations were found with master chronologies in New Jersey and Southern New York. The lack of correlation with the northern Hudson Valley and eastern New York chronologies is intriguing in that those chronologies are only $300-400 \mathrm{~km}$ from Philadelphia. The lack of correlation here, compared to stronger correlations in central Pennsylvania and central Virginia, could arise from a fairly sharp climatological boundary in the northern Hudson Valley. This finding would corroborate a changing climatic response in $Q$. alba moving up the Hudson valley (Pederson et al. 2004). The individual series correlations of the WTC samples with the WTC chronology suggest that most if not all of the timbers used to build the ship came from the same forest in the Philadelphia area.

The very narrow tree-ring widths found in the analyzed samples (with an overall mean and standard deviation of $1.05 \pm 0.06 \mathrm{~mm} \mathrm{year}{ }^{-1}$; Figure 4) suggest the trees originated from dense old growth forests. These primeval forests were substantially affected by European settlers as early as the $17^{\text {th }}$ Century (Williams 1992). In this period logging was typically carried out first along the major waterways and the coast before continuing further inland.

\section{Dating}

According to the outer rings of seven dated samples (Table 1), the construction date of the ship was most likely 1773 or soon after. Although we did not observe bark in any samples, the seven samples dating to 1762 or later had between 15 and 41 sapwood rings, suggesting that relatively few rings, if any, were missing from the outer part of the timbers (Hughes et al. 1981). These results would support the hypothesis of an early 1770 s construction date for the ship. Assuming that few rings are missing from the edges of two samples dating to 1732 and 1743 , it would suggest that the timbers might have been obtained from already dead trees or older timbers may have been reused (Farrell and Baillie 1976). Further, sample OUT8 (dated to 1732) was dislocated from the ship remnant when it was found and although it appeared to represent a displaced ship frame, it is possible that the sample was not in fact part of the ship. The rest of the timbers, with outer dates back as early as 1650 , had been squared prior to construction; no waney edge or sapwood rings were present in these samples. Therefore, the outermost tree rings from these samples can be interpreted only in support of a terminus post quem (earliest possible) construction date of 1773 . The latest possible period of construction would be the 1790s, when the site where the ship was uncovered had been filled in (AKRF 2013). Assuming the older date of 1773 as the date for the felling of the trees, we can conclude a construction date of the mid to late 1770 s, allowing for a few years for the seasoning of the wood (Farrell and Baillie 1976). These results would indicate that the vessel was in operation for at most 20 to 30 years before being abandoned or sinking in what was then a harbor on the west side of Lower Manhattan.

A close examination of the WTC ship chronology and the Philadelphia master chronologies shows two simultaneous reductions of growth in the late 1660s and 1690s supporting the hypothesis that the trees used to develop both chronologies originated from the same locality. Most likely the shipyard where the ship was constructed was close to where the trees were felled. This evidence appears to support a hypothesis put forth by Norman Brouwer (AKRF 2013), who stated that based on certain idiosyncratic aspects of the vessel's construction, it may have 
been built at a small rural shipyard rather than a large, established, and well-financed shipyard (AKRF 2013). A small shipyard may have been more likely to take limited timber stock from a single geographic location for the construction of a vessel. According to Scharf and Westcott (1884), shipbuilding was an important industry in eastern Pennsylvania and Philadelphia from as early as 1693 through the 1770s. In 1698, the shipyards in the city were observed to "have very stately oaks to build ships with" and that "logs of pine, hemlock, and oak are cut for ship frames, and wharf timbers" (Scharf and Westcott 1884; p. 2336, 2244), suggesting that at the time adequate timber for ship-building was almost certainly available in the Philadelphia area.

Our dendrochronological analysis provides a number of crucial insights into the history and origin of the World Trade Center ship. First, it provides an approximate construction date for the ship. In North America, few 18th Century ships have been found and little historical documentation survives of how vessels of this period were constructed. Therefore, confirmation of the ship's date was important in establishing that the hull uncovered at the World Trade Center represented a rare and valuable piece of shipbuilding history in the United States. The construction date of 1773 or soon after and the history of Manhattan indicate that the ship had a short life span before becoming part of the landfill. Hard use, repairs, and shipworm infestation may have contributed to the ship's demise. Evidence that the vessel may have made at least one trip to the Caribbean suggests that, although the ship was constructed for use in a river environment, it may have actually been used to transport cargo much farther afield, possibly undermining the condition of the vessel. The dendrochronological analysis also confirmed the American origin of the timbers, and yielded evidence that it was most likely built in the Philadelphia area. Lastly, the analysis suggests that the oak timbers used to build the vessel frame likely originated in the same specific location, lending credence to the notion that the ship was the product of a small shipyard.

\section{ACKNOWLEDGMENTS}

The authors wish to thank the Lower Manhattan Development Corporation, the Port Authority of New York and New Jersey (PANYNJ), and the project team, including the archaeologists and historians of AKRF, including A. Michael Pappalardo, Elizabeth Meade, and Diane Dallal; consulting maritime historians including Carrie Atkins Fulton, Warren Riess, and Norman Brouwer; and the Maryland Archaeological Conservation Laboratory. We thank Kevin J. Eckelberger (Professor of Marine Biology and Director of the Darling Marine Center at the University of Maine) and Robert A. Blanchette, (Department of Plant Pathology at the University of Minnesota). Photos of the site and the ship are courtesy of Lower Manhattan Development Corporation (LMDC). The editor and two anonymous reviewers provided suggestions that helped improve an earlier version of this manuscript. Lamont-Doherty Earth Observatory Contribution No. 7776. We acknowledge support to the Fulbright-MICIIN postdoctoral fellowship awarded to DMB and the IOF-Marie Curie Fellowship PIOF-GA-2009253277 to LAH. Funding was provided by the Lower Manhattan Development Corporation (LMDC) and the Port Authority of New York and New Jersey (PANYNJ) through grant AKRF CU10-2.

\section{REFERENCES}

AKRF, 2013. Final Technical Report: World Trade Center Memorial and Development Plan: Data Recovery and Analysis of WTC Ship. Prepared by AKRF, Inc. for the Lower Manhattan Development Corporation.

Bonde, N., and A. E. Christensen, 1993. Dendrochronological dating of the Viking Age ship burials at Oseberg, Gokstad and Tune, Norway. Antiquity 67:575-583.

Bridge, M., 2012. Locating the origins of wood resources: A review of dendroprovenancing. Journal of Archaeological Science 39:2828-2834.

Buttenwieser, A., 1987. Manhattan Waterbound: Planning and Developing Manhattan's Waterfront From the Seventeenth Century to the Present. New York University Press, New York

Carrell, T. L., 2003. From forest to fairway: hull analysis of ' $\mathrm{La}$ Belle', a late seventeenth-century French ship. Ph.D. thesis, Maritime Studies, University of St. Andrews, U.K.

Cook, E. R., and W. Callahan, 1992. The Development of a Standard Tree-Ring Chronology for Dating Historical 
Structures in the Greater Philadelphia Region. Tree-Ring Laboratory, Lamont-Doherty Geological Observatory, Columbia University, New York.

Cook, E. R., and W. J. Callahan, 2004. Tree-Ring Dating of the Dismantled Timbers of the Daniel Pieter Winne House, Bethlehem, New York. Tree-Ring Laboratory, LamontDoherty Geological Observatory, Columbia University, New York. [http://www.hvva.org/winne.pdf]

Cook, E. R., and W. J. Callahan, 2005. A Dendrochronological Analysis of the West Camp House. Tree-Ring Laboratory, Lamont-Doherty Geological Observatory, Columbia University, New York. [http://www.hvva.org/westcamphouse.pdf]

Cook, E. R., and G. C. Jacoby, 1977. Tree-ring-drought relationships in the Hudson Valley, New York. Science 198: 399-401.

Cook, E. R., and G. C. Jacoby, 1983. Potomac River streamflow since 1730 as reconstructed by tree rings. Journal of Climate and Applied Meteorology 22:1659-1672.

Cook, E. R., D. M. Meko, D. W. Stahle, and M. K. Cleaveland, 1999. Drought reconstructions for the continental United States. Journal of Climate 12:1145-1162.

Daly, A., 2007. The Karschau ship, Schleswig-Holstein: Dendrochronological results and timber provenance. International Journal of Nautical Archaeology 36:155-166.

Daly, A., and P. Nymoen, 2008. The Bøle ship, Skien, Norway research history, dendrochronology and provenance. International Journal of Nautical Archaeology 37:153-170.

Douglass, A., 1921. Dating our prehistoric ruins: How growth rings in trees aid in the establishing the relative ages of the ruined pueblos of the southwest. Natural History 21:27-30.

Douglass, A. E., 1929. The secret of the southwest solved by talkative tree rings. National Geographic Magazine 56: 736-770.

Farrell, A. W., and M. G. L. Baillie, 1976. The use of dendrochronology in nautical archaeology. Irish Archaeological Research Forum 3:45-55.

Grissino-Mayer, H. D., 2009. Preface - An introduction to dendroarchaeology in the southeastern United States. TreeRing Research 65:5-10.

Grissino-Mayer, H. D., J. T. Maxwell, G. L. Harley, N. A. Garland, D. H. Holt, C. Absher, B. J. Beale, M. S. Boehm, K. A. de Graauw, A.-M. Rautio, and A. W. Dye, 2012. Dendrochronology reveals the construction history of an early 19th century farm settlement, southwestern Virginia, USA. Journal of Archaeological Science 40:481-489.

Haneca, K., T. Wazny, J. Van Acker, and H. Beeckman, 2005. Provenancing Baltic timber from art historical objects: Success and limitations. Journal of Archaeological Science 32:261-271.

Holmes, R. L., 1983. Computer-assisted quality control in treering dating and measurement. Tree-Ring Bulletin 43:69-78.

Huber, G. D., 2006. Abbott Lowell Cummings' prescience and dates for first period houses of Massachusetts Bay Colony using dendrochronology. Material Culture 38: 39-52.

Hughes, M. K., S. J. Milsom, and P. A. Leggett, 1981. Sapwood estimates in the interpretation of tree-ring dates. Journal of Archaeological Science 8:381-390.
Krusic, P. J., M. Kenney, and J. Hornbeck, 1987. Preparation of increment cores for tree-ring measurement. Northern Journal of Applied Forestry 4:104-105.

Krusic, P. J., W. E. Wright, and E. R. Cook, 2004. Tree-Ring Dating of the Cahn House New Paltz, New York. Tree-Ring Laboratory, Lamont-Doherty Geological Observatory, Columbia University, New York. [http://www.hvva.org/cahn. pdf]

Manos, P. S., and D. E. Stone, 2001. Evolution, phylogeny, and systematics of the Juglandaceae. Annals of the Missouri Botanical Garden 88:231-269.

McDonald, T. C., 2006. The fundamental practice of fieldwork at Colonial Williamsburg. Perspectives in Vernacular Architecture 13:36-53.

Miles, D., 1997. The interpretation, presentation and use of tree-ring dates. Vernacular Architecture 28:40-56.

Nixon, K. C., 2006. Global and neotropical distribution and diversity of oak (genus Quercus) and oak forests. In Ecology and Conservation of Neotropical Montane Oak Forests, edited by M. Kappelle, pp. 3-13. Springer-Verlag, Berlin, Germany.

Pederson, N., E. R. Cook, G. C. Jacoby, D. M. Peteet, and K. L. Griffin, 2004. The influence of winter temperatures on the annual radial growth of six northern-range-margin tree species. Dendrochronologia 22:7-29.

Pederson, N., A. R. Bell, E. R. Cook, U. Lall, N. Devineni, R. Seager, K. Eggelston, and K. J. Vranes, 2012a. Is an epic pluvial masking the water insecurity of the greater New York City region? Journal of Climate 26:1339-1354.

Pederson, N., K. Tackett, R. W. McEwan, S. Clark, A. Cooper, G. Brosi, R. Eaton, and R. D. Stockwell, 2012b. Long-term drought sensitivity of trees in second-growth forests in a humid region. Canadian Journal of Forest Research 42: 1837-1850.

Pickard, F., A. Robichaud, and C. P. Laroque, 2011. Using dendrochronology to date the Val Comeau canoe, New Brunswick and developing an eastern white pine chronology in the Canadian Maritimes. Dendrochronologia 29: $3-8$.

Robinson, W. J., 1976. Tree-ring dating and archaeology in the American southwest. Tree-Ring Bulletin 36:9-20.

Scharf, J. T., and T. Westcott, 1884. History of Philadelphia, 1609-1884, Volume 3. Everts \& Co, Philadelphia.

Squires, D. F., 1992. Quantifying anthropogenic shoreline modification of the Hudson River and Estuary from European contact to modern time. Coastal Management 20: 343-354.

Stahle, D. W., M. K. Cleaveland, and J. G. Hehr, 1985. A 450year drought reconstruction for Arkansas, United States. Nature 316:530-532.

Stahle, D. W., and M. K. Cleaveland, 1988. Texas drought history reconstructed and analyzed from 1698 to 1980. Journal of Climate 1:59-74.

Stahle, D. W., M. K. Cleaveland, D. B. Blanton, M. D. Therrell, and D. A. Gay, 1998. The Lost Colony and Jamestown droughts. Science 280:564-567.

Stahle, D. W., and J. G. Hehr, 1984. Dendroclimatic relationships of post oak across a precipitation gradient in 
the southcentral United States. Annals of the Association of American Geographers 74:561-573.

Stahle, D. W., and D. Wolfman, 1985. The potential for archaeological tree-ring dating in eastern North America. Advances in Archaeological Method and Theory 8:279-302.

Stokes, M. A., and T. L. Smiley, 1968. An Introduction to Tree-Ring Dating. University of Chicago Press, Chicago, Illinois.
Therrell, M. D., and D. W. Stahle, 2012. Tree-ring dating of an Arkansas antebellum plantation house. Tree-Ring Research 68:59-67.

Williams, M., 1992. Americans and Their Forests: A Historical Geography. Cambridge University Press, UK.

Received 20 November 2012; accepted 13 April 2014. 